ARTICLE

\title{
Comparison of parasite diversity of intertidal fish assemblages from central California and central Chile
}

Comparación de la diversidad parasitaria de ensambles de peces intermareales de las costas de California y Chile central

\section{Ítalo Fernández-Cisternas ${ }^{1}$, Mario George-Nascimento ${ }^{2}$ and F. Patricio Ojeda ${ }^{1^{*}}$}

\author{
'Departamento de Ecología, Facultad de Ciencias Biológicas, Pontificia Universidad Católica de Chile, Avda. Libertador Bernardo \\ O’Higgins 340, CP 6513677, Santiago, Chile.*pojeda @ bio.puc.cl \\ ${ }^{2}$ Departamento de Ecología, Facultad de Ciencias, Universidad Católica de la Santísima Concepción, Alonso de Ribera 2850, \\ Concepción, Chile
}

\begin{abstract}
Resumen.- Las costas de Chile y California central representan importantes puntos de comparación para el estudio de convergencias ecológicas como la composición de parásitos en distintos hospederos. Ambas costas presentan similares condiciones ambientales junto con compartir muchas familias de distintas especies. Se analizó la diversidad parasitaria de especies de peces de ambas zonas comparando si existe similitud entre estas faunas, además se determinó la presencia de 6 grupos taxonómicos de parásitos a través de la literatura y en bases de datos para cada zona (Chile y California). Se creó una matriz de presencia ausencia para las especies de peces estudiadas de ambas zonas y se realizó un análisis de similitud para probar si la composición parasitaria era similar. Los taxones de parásitos mayormente encontrados en peces de California Central correspondieron a digeneos y nemátodos mientras que en Chile central se encontró una mayor diversidad (Digenea, Annelida, Copepoda, Acanthocephala y Nematoda). El análisis de similitud mostró que las comunidades parasitarias entre Chile y California son diferentes significativamente, sin embargo, se obtuvieron sobreposiciones en la diversidad parasitaria agrupándose los hospedadores en 3 grupos, uno de los cuales estuvo conformado por hospedadores de ambas zonas. Esta diferencia puede ser explicada por la reducida diversidad de parásitos en el ensamble de peces del intermareal rocoso en California, tal vez debido a los escasos estudios existentes sobre parásitos de peces intermareales en California, junto con posibles factores no estudiados hasta el momento.
\end{abstract}

Palabras clave: Peces intermareales, parásitos, Chile, California, similitud, diversidad parasitaria, convergencia evolutiva

Abstract.- The coasts of central Chile and central California are important points of comparison in the study of ecological convergence such as a host's parasite load because of their similar environmental conditions and the shared presence of many families of different species. In this study, the diversity of parasites in fish species from both zones was analyzed and compared to establish if there are similarities between them. The presence of 6 taxonomic groups of parasites was determined using published literature and databases for each location. A presence-absence matrix was created for the fish species studied in Chile and California, and a similarity analysis was carried out to prove whether the parasite loads of both zones were similar. The parasite taxa most frequently found in fish in central California were Digenea and Nematoda, whereas in central Chile the common taxa were Digenea, Annelida, Copepoda, Acanthocephala, and Nematoda. The similarity analysis showed that the parasite composition was different between zones. Nevertheless, overlaps were obtained in the parasitic diversity grouping the host in 3 host groups, one of which consists of hosts from both zones. This difference can be explained by the low parasitic diversity in the assemble of rocky intertidal fishes in California, potentially due to the limited amount of existing studies on intertidal fish parasites in California, along with other possible factors not explored in the present study.

Key words: Intertidal fish, parasites, Chile, California, similarity, parasite diversity, convergent evolution

\section{INTRODUCTION}

Parasites play an important role within ecosystems (Hudson $e t$ al. 2006). Understanding and studying the role that they play in trophic networks is particularly important since many have a negative impact on host biology (e.g., greater vulnerability to predators). Lafferty (2008) describes how Euhaplorchis californiensis infects the brain of the California killifish, Fundulus parvipinnis, altering its behavior and making it 1030 times more vulnerable to predation by birds. In addition, it 
is worth understanding parasites since many nematodes, trematodes, cestodes, and acanthocephalans depend on a definitive host and usually need intermediary hosts to complete their lifecycles (Lafferty 1999). Due to the fact that many parasites are trophically transmitted to their hosts, the diets of host animals act as indicators of the type of parasite that could appear in each host as well as the intensity of the parasitic transmission within the trophic chain (Aldana et al. 2002). Changes in the diet composition within the same species can affect the parasite load of the host. In that same vein, if two hosts share similar diet, it is likely that there are similarities in their parasite fauna as well. This comparability in parasite fauna could be associated with the level of specificity that parasites demonstrate with regard to their hosts (Muñoz et al. 2009). In this way, parasites can be generalists (i.e., several species within a habitat assemblage may host a parasite) or specialists (i.e., only select species may host a parasite), and may be due to phylogenetic factors (Bush et al. 1990, Cabaret 2003) as well as ecological factors (Rohde 1984). Genetically similar species are more likely to share a comparable collection of parasites than species that are more phylogenetically distant from one another. Nevertheless, parasite communities in one location may be modified by elements of the hosts' ecology such as the type of habitat, environmental conditions, host diet, and/or their distribution and its impact on the transmission of parasites (Muñoz \& Castro 2012). Nonetheless, both factors play important roles in the parasitic community composition in any given habitat.

The coasts of central California $\left(34-39^{\circ} \mathrm{N}\right)$ and those of central Chile $\left(32-37^{\circ} \mathrm{S}\right)$ are part of the Eastern Boundary Current System (EBCS); California is more specifically associated with the California Current System, and Chile mainly with the Humboldt Current System. Both zones respond similarly to oceanographic and climatologic dynamics (e.g., El Niño, La Niña) (Mendelssohn \& Schwing 2002), and are also characterized by the appearance of cold water masses with high nutrient concentrations, a product of upwelling caused by both currents. This results in a large amount of primary productivity that provides energy to a rich, diverse community of both invertebrates and vertebrates in the pelagic and coastal zones (Arntz et al. 2006). The intertidal zones of both coasts provide habitats that have physical similarities such as climate, rocky outcrops, and tidal flow, all of which apply the same selective pressure on the organisms that live in the area. In turn, both coasts show great diversity in their intertidal fish assemblages (Boyle \& Horn 2006). These comparable selective pressures could cause an evolutionary convergence between distinct, phylogenetically unrelated species, suggesting a certain degree of similarity in the ecology and morphology between them (Boyle \& Horn 2006, Melville et al. 2006, Muñoz \&
Cortés 2009). For these reasons, these two geographical areas provide locations to carry out comparative studies, particularly regarding the study of ecological convergence of species assemblages from distinct geographical areas with similar selective pressures; such is the case of a host's parasitic diversity.

Both coasts boast extensive studies on coastal parasites in communities. There is a wide range of studies on parasites in rocky intertidal organisms along the coast of central Chile, including parasites of fish (e.g., Flores \& George-Nascimento 2009, Muñoz \& Castro 2012). In central California, there has also been a great deal of concern surrounding the role played by parasites in the trophic networks of marine and marsh ecosystems, and this topic has been well studied (e.g., Love \& Moser 1983, Williams et al. 1992, Hudson et al. 2006).

Many studies have demonstrated a decline in the parasitic similarity in marine fish as geographical distance between host species increases, indicating that the number of specialist parasite species decreases as the distribution of hosts grows (Kennedy \& Bush 1994, Poulin 2003, Oliva \& González 2005). Despite this, these studies also take into account the parasitic similarity for the same species within a range of study that considers the hemisphere itself and its significant latitudinal variation with respect to oceanographic conditions (e.g., significant climatic differences between northern, central, and southern Chile). The current study attempts to explore the parasitic similarity in phylogenetically unrelated hosts that experience comparable environmental pressures in different hemispheres.

For this study, two groups of fish belonging to the rocky intertidal habitats of California and central Chile were utilized, drawing on the work of Boyle \& Horn (2006). According to Boyle \& Horn (2006), these two groups are limited to 6 body forms, 4 of which the fish of both Chile and California share despite lacking a close phylogenetic relationship. In their study, the authors observed a close relationship between the morphology and diet of fish from both the Chilean and Californian assemblages, both of which belong to analogous alimentary guilds as a result of an evolutionary convergence between taxa of different regions.

The main objective of this study was to analyze and compare the parasite diversity of intertidal fish species assemblages from the central Californian and central Chilean coasts, and then determine whether the parasite communities within intertidal fish are similar in terms of diversity. Although these geographic areas differ in taxonomic composition, they occur in quite comparable physical habitats, suggesting that they would demonstrate similar biological patterns. The secondary objective was to establish whether the hosts groups themselves in categories of parasites by way of an overlapping of parasitic diversity. 
Table 1 Presence-absence of parasite families occuming in intertidal fish species of central Chile (plain text) and central Califomia (bold text). The presence of the parasite family in a host is represented with an $\mathbf{x}$ / Presencia-ausencia de familia de parásitos que ocurren en peces intermareales de Chile central (texto simple) y California central (texto negrita). La presencia de cada familia de parásito se representa con una ' $X$ '

\begin{tabular}{|c|c|c|c|c|c|c|c|c|c|c|c|c|c|c|c|c|c|c|c|c|c|c|c|c|c|c|c|c|c|c|c|c|c|}
\hline Host (family) specie & 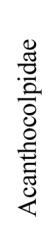 & 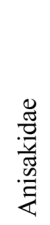 & 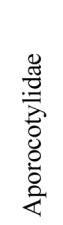 & 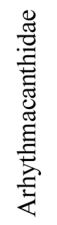 & 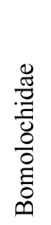 & 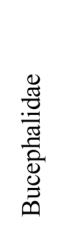 & $\begin{array}{l}\frac{\mathscr{J}}{50} \\
\frac{.0}{\pi} \\
\tilde{J}\end{array}$ & 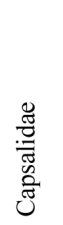 & 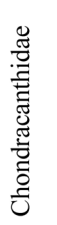 & 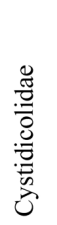 & 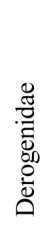 & 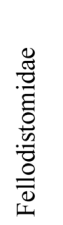 & 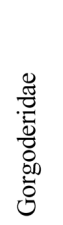 & 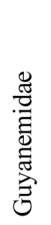 & 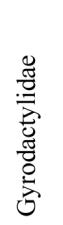 & 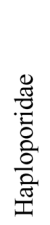 & 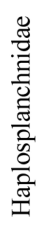 & 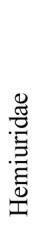 & 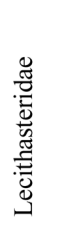 & 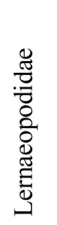 & 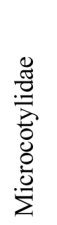 & 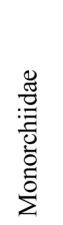 & 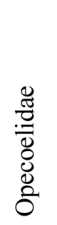 & 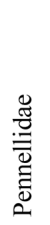 & 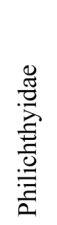 & 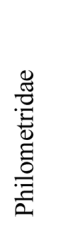 & 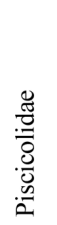 & 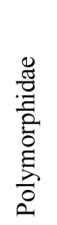 & 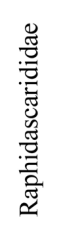 & 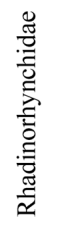 & 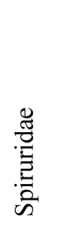 & 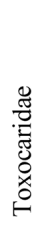 & 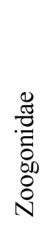 \\
\hline \multicolumn{34}{|l|}{ Blenniidae } \\
\hline Hypsoblennius sordidus & & $\mathrm{x}$ & & $\mathrm{x}$ & & $\mathrm{x}$ & $\mathrm{x}$ & $\mathrm{x}$ & & $\mathrm{x}$ & & & & & & & & & $\mathrm{x}$ & & $\mathrm{x}$ & & & $\mathrm{x}$ & & & $\mathrm{x}$ & & & & & & \\
\hline Scartichthys viridis & & $\mathrm{x}$ & & & $\mathrm{x}$ & $\mathrm{x}$ & $\mathrm{x}$ & $\mathrm{x}$ & $\mathrm{x}$ & $\mathrm{x}$ & $\mathrm{x}$ & $\mathrm{x}$ & & $\mathrm{x}$ & & $\mathrm{x}$ & & & $\mathrm{x}$ & & $\mathrm{x}$ & & $\mathrm{x}$ & & $\mathrm{x}$ & & $\mathrm{x}$ & $\mathrm{x}$ & & & & & \\
\hline \multicolumn{34}{|l|}{ Bovichthydae } \\
\hline Bovichtus chilensis & & & & $\mathrm{x}$ & $\mathrm{x}$ & & $\mathrm{x}$ & & & $\mathrm{x}$ & $\mathrm{x}$ & & & & & & & $\mathrm{x}$ & & & $\mathrm{x}$ & & & $\mathrm{x}$ & & $\mathrm{x}$ & $\mathrm{x}$ & $\mathrm{x}$ & & & $\mathrm{x}$ & & \\
\hline \multicolumn{34}{|l|}{ Clinidae } \\
\hline Gibbonsia metzi & & & & & & & & & & & & & $\mathrm{x}$ & & & & & & & & & & $\mathrm{x}$ & & & & & & & & & & \\
\hline Gibbonsia montereyensis & & & & & & & & & & & & & & & & & & $\mathrm{x}$ & & & & & $\mathrm{x}$ & & & & & & & & & & \\
\hline \multicolumn{34}{|l|}{ Cottidae } \\
\hline Artedius harringtoni & $\mathrm{x}$ & $\mathrm{x}$ & & & & & & & $\mathrm{x}$ & $\mathrm{x}$ & & & & & & & & & & $\mathrm{x}$ & & & & & & & & & & & & & \\
\hline Clinocottus analis & & & & & & & & & & & & & & & & & & $\mathrm{x}$ & & & & & $\mathrm{x}$ & & & & $\mathrm{x}$ & & & & & & \\
\hline Myxodes viridis & & & & $\mathrm{x}$ & & & $\mathrm{x}$ & & $\mathrm{x}$ & & $\mathrm{x}$ & & & & & & & & $\mathrm{x}$ & & & & $\mathrm{x}$ & $\mathrm{x}$ & & & $\mathrm{x}$ & $\mathrm{x}$ & & $\mathrm{x}$ & & & \\
\hline Oligocottus maculosus & & $\mathrm{x}$ & & & $\mathrm{x}$ & & & & $\mathrm{x}$ & & & & & $\mathrm{x}$ & $\mathrm{x}$ & & & $\mathrm{x}$ & $\mathrm{x}$ & & & & $\mathrm{x}$ & & & & $\mathrm{x}$ & & & & & & \\
\hline Oligocottus snyderi & & & & & & & & & & & & & & & & & & & $\mathrm{x}$ & & & & $\mathrm{x}$ & & & & $\mathrm{x}$ & & & & & & $\mathrm{x}$ \\
\hline Scorpaenichthys marmoratus & & & & & $\mathrm{x}$ & $\mathrm{x}$ & $\mathrm{x}$ & & $\mathrm{x}$ & $\mathrm{x}$ & & & & & & & & $\mathrm{x}$ & & & & & $\mathrm{x}$ & & & & $\mathrm{x}$ & & & & & & \\
\hline \multicolumn{34}{|l|}{ Embiotocidae } \\
\hline Micrometrus minimus & & & & & & & & & & & & & & & & & $\mathrm{x}$ & & & & & $\mathrm{x}$ & $\mathrm{x}$ & & $\mathrm{x}$ & & & & & & & & $\mathrm{x}$ \\
\hline \multicolumn{33}{|l|}{ Gobiesocidae } & \\
\hline Gobiesox maeandricus & & & & & & & & & & & & & & $\mathrm{x}$ & & & & $\mathrm{x}$ & & & & & $\mathrm{x}$ & & & $\mathrm{x}$ & & & & & & & \\
\hline Gobiesox marmoratus & & & $\mathrm{x}$ & $\mathrm{x}$ & $\mathrm{x}$ & & $\mathrm{x}$ & $\mathrm{x}$ & & $\mathrm{x}$ & $\mathrm{x}$ & $\mathrm{x}$ & & $\mathrm{x}$ & & & & & $\mathrm{x}$ & & $\mathrm{x}$ & & $\mathrm{x}$ & $\mathrm{x}$ & & & $\mathrm{x}$ & $\mathrm{x}$ & & $\mathrm{x}$ & & & \\
\hline Sicyases sanguineus & & & & & & $\mathrm{x}$ & $\mathrm{x}$ & & $\mathrm{x}$ & & & $\mathrm{x}$ & & & $\mathrm{x}$ & & & & $\mathrm{x}$ & & & & $\mathrm{x}$ & $\mathrm{x}$ & & & $\mathrm{x}$ & & & & & & \\
\hline \multicolumn{34}{|l|}{ Kyphosidae } \\
\hline Girella laevifrons & & $\mathrm{x}$ & & & & $\mathrm{x}$ & $\mathrm{x}$ & $\mathrm{x}$ & & $\mathrm{x}$ & & & & & & & & & & $\mathrm{x}$ & & & & & & & & & & $\mathrm{x}$ & & & \\
\hline Graus nigra & & & & & & & $\mathrm{x}$ & & & $\mathrm{x}$ & & & & & & & & & $\mathrm{x}$ & & & & & & & & $\mathrm{x}$ & $\mathrm{x}$ & & & & & \\
\hline \multicolumn{34}{|l|}{ Labrisomidae } \\
\hline Auchenionchus variolosus & & & & $\mathrm{x}$ & $\mathrm{x}$ & $\mathrm{x}$ & $\mathrm{x}$ & $\mathrm{x}$ & $\mathrm{x}$ & & & & & & & $\mathrm{x}$ & & $\mathrm{x}$ & $\mathrm{x}$ & & $\mathrm{x}$ & & $\mathrm{x}$ & $\mathrm{x}$ & & & $\mathrm{x}$ & $\mathrm{x}$ & & & $\mathrm{x}$ & & \\
\hline Calliclinus geniguttatus & & & & $\mathrm{x}$ & $\mathrm{x}$ & $\mathrm{x}$ & $\mathrm{x}$ & $\mathrm{x}$ & & & & & & & & & & & & & $\mathrm{x}$ & & $\mathrm{x}$ & $\mathrm{x}$ & $\mathrm{x}$ & & $\mathrm{x}$ & $\mathrm{x}$ & & & & & \\
\hline Auchenionchus microcirrhis & & $\mathrm{x}$ & & $\mathrm{x}$ & $\mathrm{x}$ & $\mathrm{x}$ & $\mathrm{x}$ & $\mathrm{x}$ & $\mathrm{x}$ & $\mathrm{x}$ & $\mathrm{x}$ & & & & & & & & $\mathrm{x}$ & & $\mathrm{x}$ & & $\mathrm{x}$ & $\mathrm{x}$ & $\mathrm{x}$ & & $\mathrm{x}$ & $\mathrm{x}$ & & & & & \\
\hline \multicolumn{34}{|l|}{ Pholidae } \\
\hline Apodichthys flavidus & & $\mathrm{x}$ & & & & & & $\mathrm{x}$ & & & & & & & & & & & & & & & $\mathrm{x}$ & & & & & & & & & & \\
\hline \multicolumn{34}{|l|}{ Stichaeidae } \\
\hline Anoplarchus purpurescens & & $\mathrm{x}$ & & & & & & & & $\mathrm{x}$ & & & & & & & & $\mathrm{x}$ & $\mathrm{x}$ & & & & & & & & & & & & & $\mathrm{x}$ & \\
\hline Xiphister atropurpureus & & & & & & & $\mathrm{x}$ & & $\mathrm{x}$ & & & & & & & & & & & & & & $\mathrm{x}$ & & & $\mathrm{x}$ & & & & & & & \\
\hline Xiphister mucosus & & & & & & & & & & & & & & & & & & & & & & & $\mathrm{x}$ & & & & & & & & & & \\
\hline \multicolumn{34}{|l|}{ Tripterygiidae } \\
\hline Helcogrammoides chilensis & & & & & $\mathrm{x}$ & $\mathrm{x}$ & $\mathrm{x}$ & & & & $\mathrm{x}$ & & & & $\mathrm{x}$ & & & & $\mathrm{x}$ & & & & $\mathrm{x}$ & & & & $\mathrm{x}$ & $\mathrm{x}$ & & & & & \\
\hline Helcogrammoides cunninghami & & & & $\mathrm{x}$ & & $\mathrm{x}$ & & & & & & & & & & & & $\mathrm{x}$ & & & & & & & & $\mathrm{x}$ & & & & & & & \\
\hline
\end{tabular}




\section{MATERIALS AND METHODS}

\section{BibLIOGRAPHIC COLLECTION}

Two lists of the most typical intertidal fish species were created, one for central California and another for central Chile. In total, the study covered 26 species of fish. For the assemblage from the coasts of central California, a list of 13 from 14 fish was taken from an assemblage described in the work of Boyle \& Horn (2006). For central Chile, a list of 13 fish was taken from the work of Muñoz \& Ojeda (1997), which Boyle \& Horn (2006) also utilized. Subsequently, different studies and databases were consulted to check whether the parasite species - within to the taxonomic groups selected (annelids, cestodes, digeneans, nematodes, acanthocephalans, monogeneans, and copepods) - were hosted by the analyzed fish species. Due to a lack of information in the literature about their parasites, the host species Xerepes fucorum (Pholidae), Micrometrus aurora (Embiotocidae), Scythalina cerdale (Scytalinidae), Artedius latteralis (Cottidae), and Oligocottus rubellio (Cottidae) on the list of fish from central California were replaced by other abundant species of the Californian intertidal rocky zone in similar families: Apodichthys flavidus (Pholidae), Micrometrus minimus (Embiotocidae), Scorpaenichthys marmoratus (Cottidae), Artedius harringtoni (Cottidae), and Oligocottus maculosus (Cottidae). Only studies and databases that report parasite presence in a host within the range of study were selected, meaning those that were within or near the regions of central California $\left(34-39^{\circ} \mathrm{N}\right)$ and central Chile $\left(32-37^{\circ} \mathrm{S}\right)$. However, due to the low quantity of literature found for California, work completed in the more northern region of California was considered as belonging to the zoographic zone of the Oregonian Province. This zone extends from Point Conception to the border of British Columbia-Alaska. Thirteen scientific works from California were used, two of which correspond to the complete bibliographic lists of parasites and their hosts. Thirteen scientific works from Chile were also used in the present study, two of which also correspond to the same bibliographic lists. For the Chilean portion of the analysis, a data matrix from the project FONDECYT 1130304 involving the presence of parasites in distinct tidepool fish of Chile central was used. The parasite diversity for each species of fish was described in terms of the parasite species present in different study areas. For the purposes of this study, the absence of a species of parasite in a fish signifies that there was no record of parasitism for this species in the case of that particular individual. The presence of a parasite, on the other hand, means that there is at least one record of that species found in a host. Most larval cestodes have been described to order rather than by family, they were not considered in this study. The parasites identified up to family, genus, or species level were considered in analyses of this study. The entire list of parasite species found in each host species may be referenced in Appendix 1.

\section{Parasite-host analyses}

The species of parasites found were ordered and classified by family. Then, a similarity matrix of the parasitic diversity of each host was constructed, with the parasite family composition (Table 1) in a presence/absence matrix containing the two assemblages of fish from the rocky intertidal in central California and central Chile.

Using the software Primer 6, a similarity cluster for the parasite occurrence matrix using the Jaccard index was developed. Then, a similarity profile analysis (SIMPROF) was performed to detect the possibility of groups overlapping with respect to the parasite diversity between hosts. In order to evaluate if the parasitic diversity between both zones was similar, a two-dimensional MDS (Non-metric Multidimensional Scaling) graph was created. Nonparametric analyses were performed to analyze parasite similarity within and between the fish communities. In order to evaluate and statistically confirm the results obtained using the MDS, a one-way analysis of similarity (ANOSIM) was conducted, testing whether the parasite diversity in hosts from each site is similar to the other site in question. The test largely consists of comparing the differences in the parasite communities of each site with the differences within the site, in this case between central Chile and central California. Finally, a one-way similarity percentage analysis (SIMPER) was used to explore which genera of parasites contributed the most to the similarities as well as the differences between zones.

\section{Results}

\section{BibliograPhic COLLECTION}

There is more information available with regard to parasitism in fish on the central Chile list than for those on the central California list. There were few studies available demonstrating incidences of parasitism in fish on the California list. Indeed, at times, only a single study determined the rate of parasitism by a certain taxon in a given species of fish. All taxa of parasites studied (cestodes, nematodes, digeneans, acanthocephalans, copepods) were found in the list of hosts within central Chile. However, in the case of California, there were no records of acanthocephalans in any of the fish, neither in the literature nor the consulted databases. Digenea is the only taxonomic group that was recorded in all fish species of both geographic regions. There were 65 new records of parasite species found 


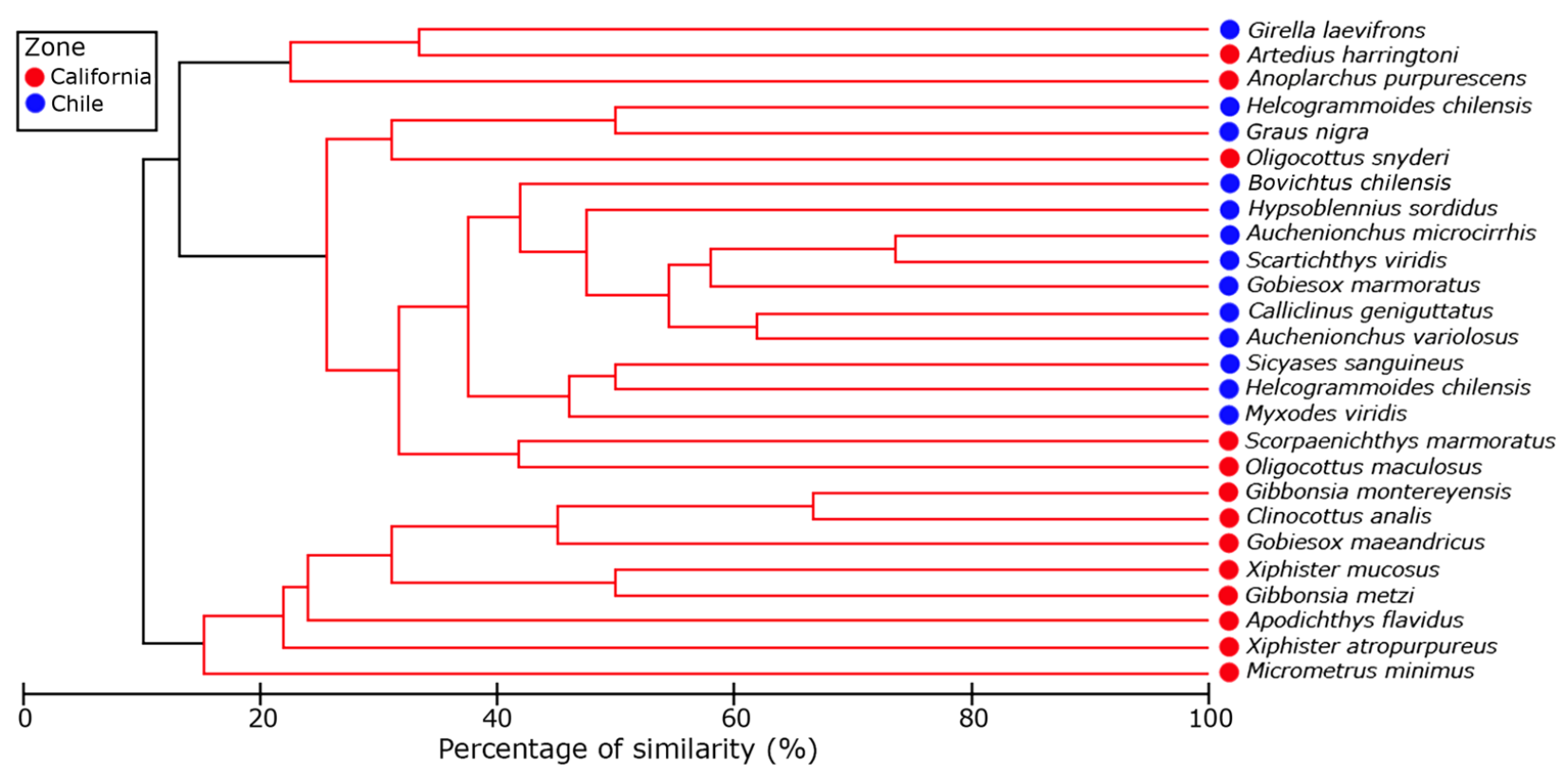

Figure 1. Parasitic similarity dendrogram (SIM PROF) for 13 Californian intertidal fish species (red circles) and 13 Chilean intertidal fish species (blue circles) / Dendrograma de similitud parasitaria (SIMPROF) para 13 especies de peces intermareales de California (círculos rojos) y 13 especies de peces intermareales de Chile (círculos azules)

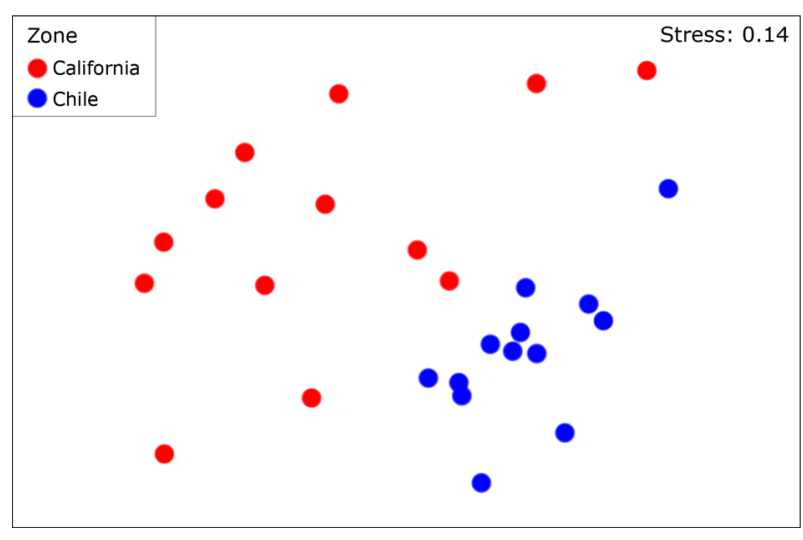

Figure 2. Spatial representation of the co-occurrence of parasite family from intertidal fishes of central Chile and central California (MDS). Blue circles represent fish species from central Chile and red circles represent fish species from central California / Representación gráfica de la co-ocurrencia de familia de parasitarios de los peces intermareales de Chile central y California central (MDS). Los círculos azules representan las especies de peces de Chile central y los círculos rojos representan las especies de peces de California central within the 13 chosen hosts in the central Chilean assemblage. In total, 115 parasite species were identified, composing of 34 families, where the families Anisakidae, Bomolochidae, Bucephalidae, Caligidae, Chondracantidae, Cystidicolidae, Guyanemidae, Gyrodactylidae, Hemiuridae, Lecithasteridae, Lernaeopodidae, Opecoelidae, Philichthydae, Philometridae, and Piscicolidae were found in both the Californian and Chilean fish (Table 1). The species that showed the greatest parasitic diversity in central Chile were Scartichthys viridis, Gobiesox marmoratus and Auchenionchus microcirrhis, each with 20 parasitic species. The Californian fish species with the greatest parasitic diversity was Scorpaenichthys marmoratus with 14 species (Appendix 1).

\section{Parasite-host analyses for parasite families}

According to the results obtained from the cluster analysis and the SIMPROF analysis to determine the degree of overlap of parasitic diversity (Fig. 1), 3 groups of hosts were identified, according to their degree of overlap. A first group separated at a percentage similarity (PS) of $11 \%$ with respect to the other groups, composed of 8 host species belonging solely to the California assemblage, and mainly represented by parasites of Anisakidae (Nematoda) and Cysticolidae (Nematoda). Alongside this, 2 other groups are recognized: a second group composed of 2 host species from California and 1 from Chile 
Table 2. Parasitic average similarity observed within intertidal fish assemblage of central Chile: The average similarity, the percentage contribution (PC\%) and the accumulative percentage contribution of each family of parasites for this similarity with their average similarity / Similitud promedio de parásitos observada dentro del ensamble de peces intermareales de Chile: Similitud promedio, contribución porcentual de la similitud (PC \%) y contribución porcentual acumulada para cada familia de parásito

\begin{tabular}{|c|c|c|c|}
\hline \multirow{2}{*}{ Family of parasites } & \multicolumn{3}{|c|}{$\begin{array}{l}\text { Fish assemblage of Chile } \\
\text { (Average similarity: } 52.83 \text { ) }\end{array}$} \\
\hline & $\begin{array}{l}\text { Average } \\
\text { Similarity }\end{array}$ & $\begin{array}{l}\text { PC } \\
(\%)\end{array}$ & $\begin{array}{c}\text { Accumulative } \\
\text { PC }(\%)\end{array}$ \\
\hline Caligidae & 9.93 & 18.79 & 18.79 \\
\hline Piscicolidae & 8.14 & 15.40 & 34.19 \\
\hline Lecithasteridae & 5.66 & 10.71 & 44.90 \\
\hline Polymorphidae & 3.92 & 7.42 & 52.33 \\
\hline Bucephalidae & 3.18 & 6.01 & 58.34 \\
\hline Bomolochidae & 3.04 & 5.76 & 64.10 \\
\hline Pennellidae & 2.96 & 5.60 & 69.71 \\
\hline Opecoelidae & 2.87 & 5.43 & 75.13 \\
\hline Cystidicolidae & 2.43 & 4.59 & 79.73 \\
\hline Arhythmacanthidae & 2.13 & 4.03 & 83.76 \\
\hline Capsalidae & 2.12 & 4.01 & 87.77 \\
\hline Microcotylidae & 1.97 & 3.73 & 91.50 \\
\hline Derogenidae & 1.48 & 2.79 & 94.29 \\
\hline Chondracanthidae & 0.98 & 1.85 & 96.15 \\
\hline Anisakidae & 0.64 & 1.21 & 97.36 \\
\hline Rhadinorhynchidae & 0.36 & 0.68 & 98.04 \\
\hline Fellodistomidae & 0.28 & 0.53 & 98.57 \\
\hline Philichthyidae & 0.26 & 0.50 & 99.07 \\
\hline Spiruridae & 0.14 & 0.27 & 99.34 \\
\hline Gyrodactylidae & 0.09 & 0.18 & 99.52 \\
\hline Hemiuridae & 0.09 & 0.18 & 99.70 \\
\hline Haploporidae & 0.08 & 0.15 & 99.85 \\
\hline Guyanemidae & 0.08 & 0.15 & 100 \\
\hline
\end{tabular}

( $\mathrm{PS}=15 \%)$, mainly represented by parasite families Lecithasteridae (Digenea) and Piscicolidae (Annelida), and another group composed of 12 host species from Chile and 3 from California ( $\mathrm{PS}=26 \%$ ), mainly represented by parasites of Piscicolidae (Annelida), Opecolidae (Digenea), and Caligidae (Copepoda).

The MDS analysis performed for the parasite community cluster for fish assemblages of Chile and California coasts showed a stress level of 0.14 (Fig. 2), suggesting an acceptable goodness of fit for the nonparametric regression behind the original similarity data (Clarke \& Warwick 2001). By examining the MDS, it is clear that the parasite diversity of fishes of both
Table 3. Parasitic average similarity observed within intertidal fish assemblage of central California: The average similarity, the percentage contribution (PC\%) and the accumulative percentage contribution of each family of parasites for this similarity with their average similarity / Similitud promedio de parásitos observada dentro del ensamble de peces intermareales de California: Similitud promedio, contribución porcentual de la similitud (PC \%) y contribución porcentual acumulada para cada familia de parásito

\begin{tabular}{lccc}
\hline & \multicolumn{3}{c}{$\begin{array}{c}\text { Fish assemblage of California } \\
\text { Family of parasites }\end{array}$} \\
\cline { 2 - 4 } & $\begin{array}{c}\text { Average } \\
\text { Similarity }\end{array}$ & $\begin{array}{c}\text { PC } \\
\text { (\%) }\end{array}$ & $\begin{array}{c}\text { Accumulative } \\
\text { PC (\%) }\end{array}$ \\
\hline Opecoelidae & 20.21 & 65.34 & 65.34 \\
Hemiuridae & 4.16 & 13.44 & 78.78 \\
Anisakidae & 1.48 & 4.78 & 83.56 \\
Piscicolidae & 1.37 & 4.45 & 88.00 \\
Chondracanthidae & 1.23 & 3.97 & 91.97 \\
Lecithasteridae & 0.67 & 2.15 & 94,12 \\
Cystidicolidae & 0.65 & 2.10 & 96,23 \\
Philometridae & 0.32 & 1.04 & 97.26 \\
Zoogonidae & 0.28 & 0.92 & 98.18 \\
Caligidae & 0.21 & 0.69 & 98.87 \\
Guyanemidae & 0.20 & 0.64 & 99.51 \\
Bomolochidae & 0.15 & 0.49 & 100 \\
\hline
\end{tabular}

coasts is significantly different from one another (Fig. 2), which was supported by ANOSIM $(P=0.001)$; the analysis also provided an R-value of 0.57 , meaning that the hosts within the same region are much more similar to each other than they are to the hosts of the other location. With the results produced by the SIMPER analysis, it appears that the hosts belonging to the Chilean fish assemblage are much more similar among themselves, obtaining an average similarity of $52.83 \%$, whereas the Californian host species displayed an average similarity of $30.9 \%$. From Chile, the families that contributed approximately $50 \%$ of this similarity were Caligidae (Copepoda) with $18.79 \%$ contribution, Piscicolidae (Annelida) with a $15.4 \%$ contribution, Lecthasteridae (Digenea) with a $10.71 \%$ contribution, and Polymorphidae (Acanthocephala) with a $7.42 \%$ contribution (Table 2). From California, only the family Opecoelidae (Digenea) contributed to more than half of the observed similarity with a contribution of $65.3 \%$ (Table 3 ). Finally, a differentiation (dissimilarity) of $78.16 \%$ was observed between the two assemblages and the families that contributed most to this difference were Caligidae (Copepoda) with a $8.22 \%$ contribution, Piscicolidae (Annelida) with $6.5 \%$ of contribution, Lecithasteridae (Digenea) with a $6.29 \%$ of contribution, Polymorphidae (Acanthocephala) with $5.84 \%$ of contribution, 
Table 4. Parasitic average dissimilarity obtained between intertidal fish assemblages of central Chile and central California: Average dissimilarity, percent contribution of each family of parasites for this dissimilarity (PC \%) and accumulative percentage contribution / Disimilitud promedio de parásitos observada dentro de cada ensamble de peces intermareales de Chile y California central: Promedio disimilitud, contribución porcentual de la disimilitud para cada familia de parásito (PC \%) y la contribución porcentual acumulada

\begin{tabular}{|c|c|c|c|}
\hline \multirow{2}{*}{ Family of parasites } & \multicolumn{3}{|c|}{$\begin{array}{l}\text { Fish assemblage of Chile } \\
\quad \text { and California } \\
\text { Average dissimilarity: } 78.16\end{array}$} \\
\hline & $\begin{array}{l}\text { Average } \\
\text { similarity }\end{array}$ & $\begin{array}{l}\mathrm{PC} \\
(\%)\end{array}$ & $\begin{array}{c}\text { Accumulative } \\
\text { PC (\%) }\end{array}$ \\
\hline Caligidae & 6.43 & 8.22 & 8.22 \\
\hline Piscicolidae & 5.08 & 6.50 & 14.72 \\
\hline Lecithasteridae & 4.92 & 6.29 & 21.01 \\
\hline Polymorphidae & 4.56 & 5.84 & 26.85 \\
\hline Bucephalidae & 4.06 & 5.19 & 32.05 \\
\hline Bomolochidae & 4.02 & 5.14 & 37.19 \\
\hline Pennellidae & 3.87 & 4.95 & 42.14 \\
\hline Cystidicolidae & 3.73 & 4.77 & 46.91 \\
\hline Opecoelidae & 3.67 & 4.70 & 51.61 \\
\hline Capsalidae & 3.39 & 4.33 & 55.94 \\
\hline Hemiuridae & 3.32 & 4.24 & 60.18 \\
\hline Arhythmacanthidae & 3.28 & 4.19 & 64.37 \\
\hline Microcotylidae & 3.09 & 3.95 & 68.33 \\
\hline Chondracanthidae & 2.99 & 3.82 & 72.15 \\
\hline Anisakidae & 2.94 & 3.76 & 75.91 \\
\hline Derogenidae & 2.77 & 3.54 & 79.45 \\
\hline Rhadinorhynchidae & 1.65 & 2.11 & 81.55 \\
\hline Philichthyidae & 1.60 & 2.05 & 83.61 \\
\hline Guyanemidae & 1.51 & 1.93 & 85.54 \\
\hline Gyrodactylidae & 1.47 & 1.88 & 87.42 \\
\hline Philometridae & 1.46 & 1.87 & 89.29 \\
\hline Fellodistomidae & 1.35 & 1.72 & 91.01 \\
\hline Lernaeopodidae & 1.13 & 1.45 & 92.46 \\
\hline Zoogonidae & 1.09 & 1.39 & 93.85 \\
\hline Spiruridae & 0.89 & 1.13 & 94.99 \\
\hline Haploporidae & 0.77 & 0.99 & 95.97 \\
\hline Gorgoderidae & 0.67 & 0.86 & 96.84 \\
\hline Acanthocolpidae & 0.52 & 0.67 & 97.50 \\
\hline Haplosplanchnidae & 0.52 & 0.67 & 98.17 \\
\hline Monorchiidae & 0.52 & 0.67 & 98.84 \\
\hline Toxocaridae & 0.52 & 0.67 & 99.51 \\
\hline Aporocotylidae & 0.38 & 0.49 & 100 \\
\hline
\end{tabular}

Bucephalidae (Digenea) with $5.19 \%$ of contribution, Bomolochidae (Copepoda) with a $5.14 \%$ of contribution, Pennellidae (Copepoda) with a $4.95 \%$ contribution, Cystidicolidae (Nematoda) with a $4.77 \%$ of contribution, and Opecoelidae (Digenea) with a $4.7 \%$ of contribution (Table 4).

\section{Discussion}

A species's morphology can be a reliable indicator of its organismal ecology in a particular habitat, as can the alimentary (i.e., diet-related) specialization that they may possess, a relationship also known as form and function (Russell 1916, Koehl 1996, Ferry-Graham et al. 2002). In Boyle \& Horn (2006), the authors found supporting evidence for a diet overlap between the fish species of central Chile and California, suggesting elements of convergent evolution between both regions. Therefore, it could be expected that the fish from these two separate assemblages would present comparable parasite communities. However, the results of the current study did not support this hypothesis; in fact, the parasite communities of each area were quite distinct, meeting one of the proposed goals. Even so, it is possible to observe a certain degree of overlap of said parasite diversity in the fish species of both assemblages, as the species grouped into four categories according to their parasitic load composition, and three of these categories consisted of central Chilean and Californian species in almost equal quantities. Interestingly, the species Helcogrammoides chilensis and Helcogrammoides cunninghami both displayed substantially low similarity in their respective parasitic communities, contrary to what has been described in the literature (Muñoz \& Cortés 2009). Instead, they are found in contrasting groups, suggesting that other factors independent of the phylogenetic relationship may affect the similarity in the parasite population of a given species. Nevertheless, this overlap does not demonstrate a pattern of similarity neither in the diet of the hosts nor in other ecological characteristics of the studied species of each group.

Even though diet plays a fundamental role in a host's resulting parasite community, there are other ecological characteristics that may affect the parasitic diversity of a host, including the size of the host, ontogeny, type of habitat, residence and migration time, abundance of the host, and gregariousness (Morand et al. 2000, Muñoz \& Cortés 2009). The body size and ontogeny combined with the residence time both play an important part in the similarity of parasites between fish species within the rocky intertidal. It has been well established that a larger body size allows for a larger quantity and diversity of parasites in a host, in part by presenting a greater resource for its parasites (Muñoz \& Cortés 2009). The large majority of works utilized for the present study consist of complete 
checklists from different regions in which there failed to exist a distinction of size of the study species, which could have an unconsidered effect on the obtained results. The distinction of the ontogenetic change is important to the description of the parasitic community of a particular species. This ontogenetic change has been well documented in rocky intertidal fish species in Chile, as is the case with Sicyases sanguineus and Bovichtus chilensis, principally associated with the change of size and diet of these species (Muñoz et al. 2002, Muñoz \& Zamora 2011). This is reflected in the separation of one species into different alimentary guilds, depending on the host's size (Muñoz \& Ojeda 1997).

One characteristic that defines rocky intertidal fish species and distinguishes them from one another is their residence time in the rocky intertidal habitat, a feature by which they are classified into the categories of resident and transient species. Resident fish and transitory fish possess differences in parasitic composition due to the fact that temporal species, which are mainly represented by juveniles, spend a short period of time in the intertidal pools. The specificity of the host results from the environmental restrictions due to the barriers of transmission of parasite larval stages of one host to another; if the host changes sites, the parasites will be different and will infect the host through trophic transmission (Gibson \& Yoshiyama 1999, Horn \& Martin 2006, Muñoz \& Cortes 2009, Muñoz \& Delorme 2011). In the case of Chile, of the two transitory species found in the intertidal - Girella laevifrons and Graus nigra (Aldana et al. 2002) - only Girella laevifrons was grouped apart from the rest of the resident species. Contrarily, the transient species from California - Micrometrus minimus and Scorpaenichthys marmoratus (Horn \& Martin 2006, Gibson \& Yoshiyama 1999) - were classified into different groups, being categorized with the other intertidal resident species of California.

The most representative families of parasites of each of the three groups formed by the host fish species are characterized as abundant and generalist within the parasitic community of the rocky intertidal. Parasite species with a wide range of hosts from different fish families (i.e., generalist) have been involved in adaptation processes in these hosts, which possibly implies host-switching, supporting the idea of similar trophic habits within the fish of each group and each site (Muñoz \& Cortes 2009). It is no surprise that the families consisting of digeneans are common to both zones, especially in central California, since the family Opecoelidae is characterized by being found in many families of fish in the world. Digeneans, just like nematodes, show great success in the habitat in which they are found, likely because they are able to undergo both sexual and asexual reproduction. Additionally, a ciliated larval state provides the larval parasites with more opportunities to encounter a potential host, allowing them to have a less strict specificity with respect to other parasites (i.e., cestodes and monogeneans) (Cribb 2005).

Although both the Chilean and Californian assemblages share families of parasites in common, California displays a lower parasitic diversity when compared to central Chile, represented almost solely by the digeneans. It is not common to observe such low parasitic diversity in such a complex and diverse community like California's rocky intertidal, which has a great diversity of tidepool fish and experiences environmental conditions similar to those of central Chile, a region that does have a quite diverse parasitic community. If one analyzes carefully how the registers of parasites found in fishes of the California intertidal are characterized, one can observe different factors that produce a low diversity of parasites in California and a consequently high difference between both zones. For example, there were not any registers of acanthocephalans for Californian intertidal fish. The recent works of parasites in Californian fish are focused mainly on freshwater and estuarine species (e.g., Fingerut et al. 2003, Lafferty et al. 2006, Kaplan et al. 2009, Shaw et al. 2010). There are few studies dedicated to parasitism in the rocky intertidal fish of California (as compared to Chile), and these mainly correspond to works within the last century. We can suppose that the low diversity found in California is mainly because of the low effort that has been dedicated to the studies. However, Burrenson \& Kalman (2006) shows that the annelid parasites of the Piscicolidae family are not very common in the rocky intertidal of California, a contradictory pattern to what has been studied of parasitic annelids in the intertidal of central Chile and the UK. Annelids are quite common parasites found on the coast of Chile as well as other assemblages of the rocky intertidal; since they are ectoparasites and undergo direct development, they are temporal in their hosts and environment (Moraga \& Muñoz 2010).

Discovering a difference in presence of parasites (absence of acanthocephalans, low abundance of annelids, and variety being mostly explained by abundant and generalist species) in California with respect to other assemblages in the rocky intertidal (Chile and UK) suggests that - despite both zones of studies possessing similar environmental conditions, many host species, and evolutionary ecologic convergences in common suggests that other factors not studied with anteriority could be affecting mainly the composition of parasites of fish in the Californian intertidal. One well-known characteristic of the rocky intertidal of California is the marked seasonal and spatial variability with regard to the abundance of tidepool fish (Yoshiyama 1981, Yoshiyama et al. 1986), which is not true 
for central Chile. It is possible to find species whose abundance decreases during winter, mainly because of the migration to deeper waters because of poor environmental conditions (e.g., larger turbulence, less food). This includes species that are typically lower in abundance in the summer months as well as species that are found in relatively similar numbers throughout the year (Grossman 1982, Moring 1986, Gibson \& Yoshiyama 1999, Horn \& Martin 2006). A parasite community is affected by local biotic and abiotic factors, including the density and abundance of the primary host, the density of the target host, and variations in temperature (Thieltges et al. 2009). It is probable that these constant shifts in abundance of certain tidepool fishes species have some effect on the parasite community in rocky intertidal of California, which could be a process not occurring to such a degree in central Chile. Despite all of the aforementioned, the large difference in parasite diversity within tidepool fish of both zones seems to be explained primarily by the lower quantity of studies performed in California. It is necessary that the number of studies on this topic and within this region increase in order to compare these two zones more accurately. It is well known that with a larger amount of parasitologic studies done, a higher degree of diversity will be recorded (Poulin \& Morand 2000). In addition to this, it is a priority to execute future studies on the spatial and temporal variation of tidepool fish abundances in central Chile, allowing for an improved foundation for ecological comparisons between the two zones.

This study is the first to apply a comparison of parasite communities in two intertidal fish assemblages that, although differing in taxonomic composition and occurring in remote places belonging to different hemispheres, are ecologically comparable to one another due to a similarity in habitat. Although four host groups were successfully formed as a result of the overlap in parasitic diversity within specimens from both regions, the parasitic communities between zones are significantly different. Additionally, the formed groups do not show a clear pattern with respect to the diet and phylogeny of the host. It will be necessary to perform new studies of registers in the parasitic community in the fishes of the rocky intertidal of California. This study calls attention to the lack of precedent information from this zone and the need to study and identify the factors that could be provoking this lack of parasitic diversity in the rocky intertidal of California.

\section{ACKNOWLEDGMENTS}

We are grateful to FONDECYT 1130304 and all its participants. We would like to thank Rodrigo De la Iglesia, Gabriela Muñoz, Arturo Navarrete, Karen González, Lidia Mansur, Cristóbal Gallegos, Florencia Becker, and Katalin Plummer for the invaluable assistance provided to make this study possible.

\section{LITERATURE CITED}

Aldana M, JM Pulgar, F Ogalde \& FP Ojeda. 2002. Morphometric and parasitological evidence for ontogenetic and geographical dietary shifts in intertidal fishes. Bulletin of Marine Science 70: 55-74.

Arai HP. 1969. Preliminary report on the parasites of certain marine fishes of British Columbia. Journal of the Fisheries Research Board of Canada 26: 2319-2337.

Arntz WE, VA Gallardo, D Gutiérrez, E Isla, LA Levin, J Mendo, C Neira, T Rowe, J Tarazona \& M Wolff. 2006. El Niño and similar perturbation effects on the benthos of the Humboldt, California, and Benguela Current upwelling ecosystems. Advances in Geosciences 6: 243-265.

Bennett SN. 1999. Host distribution and development of Pseudodelphis oligocotti (Dracunculoidea: Nematoda), a parasite of Eel grass Bed Fishes. PhD Thesis, Department of Zoology, The University of British Columbia, Vancouver, $127 \mathrm{pp}$.

Boyle KS \& MH Horn. 2006. Comparison of feeding guild structure and ecomorphology of intertidal fish assemblages from central California and central Chile. Marine Ecology Progress Series 319: 65-84.

Burreson EM \& JE Kalman. 2006. A new species of Malmiana (Oligochaeta: Hirudinida: Piscicolidae) from tidepool fishes in northern California. The Journal of Parasitology 92: 89-92.

Bush AO, JM Aho \& CR Kennedy. 1990. Ecological versus phylogenetic determinants of helminth parasite community richness. Evolutionary Ecology 4: 1-20.

Cabaret J. 2003. Relating parasite communities to host environmental conditions using phylogenetic tools. Parasite 10:287-295.

Clarke KR \& RM Warwick. 2001. Change in marine communities: An approach to statistical analysis and interpretation, 172 pp. PRIMER-E, Plymouth.

Cone DK \& H Roth. 1993. Prevalence and intensity of Gyrodactylus maculesi sp. n. (Monogenea) parasitizing gillofsculpin (Oligocottus maculosus), in coastal British Columbia Canada. Journal of the Helminthological Society of Washington 60: 1-4.

Cribb TH. 2005. Digenea (endoparasitic flukes). In: Rhode K (ed). Marine parasitology, pp. 280-286. SCIRO Publishing, Collingwood.

Díaz F \& M George-Nascimento. 2002. Estabilidad temporal de las infracomunidades de parásitos en la borrachilla Scartichthys viridis (Valenciennes, 1836) (Pisces: Blenniidae) en la costa central de Chile. Revista Chilena de Historia Natural 75: 641-649.

Díaz PE, G Muñoz \& M George-Nascimento. 2016. A new species of Hemipera Nicoll, 1913 (Digenea: Derogenidae) from fishes of the intertidal rocky zone of Chile. Acta Parasitologica 61: 516-522. 
Ferry-Graham L, D Bolnick \& P Wainwright. 2002. Using functional morphology to examine the ecology and evolution of specialization. Integrative and Comparative Biology 42: 265.

Fingerut JT, CA Zimmer \& RK Zimmer. 2003. Patterns and processes of larval emergence in an estuarine parasite system. The Biological Bulletin 205: 110-120.

Flores K \& M George-Nascimento. 2009. Las infracomunidades de parásitos de dos especies de Scartichthys (Pisces: Blenniidae) en localidades cercanas del norte de Chile. Revista Chilena de Historia Natural 82: 63-71.

Gibson RN \& RM Yoshiyama. 1999. Intertidal fish communities. In: Horn MH, KL Martin\& MA Chotkowski (eds). Intertidal fish, life in two worlds, pp. 1-6. Academic Press, San Diego.

Grossman GD. 1982. Dynamics and organization of a rocky intertidal fish assemblage: the persistence and resilience of taxocene structure. The American Naturalist 119: 611-637.

Horn M \& H Martin. 2006. Rocky intertidal zone. In: Allen LG, DJ Pondella \& MH Horn (eds). The ecology of marine fishes: California and adjacent waters, pp. 3-25. University of California Press, Berkeley.

Hudson PJ, AP Dobson \& KD Lafferty. 2006. Is a healthy ecosystem one that is rich in parasites? Trends in Ecology \& Evolution 21:381-385.

Kaplan AT, S Rebhal, KD Lafferty \& AM Kuris. 2009. Small estuarine fishes feed on large trematode cercariae: lab and field investigations. The Journal of Parasitology 95: 477-480.

Kennedy CR \& AO Bush. 1994. The relationship between pattern and scale in parasite communities: a stranger in a strange land. Parasitology 109: 187-196.

Koehl M. 1996. When does morphology matter? Annual Review of Ecology and Systematics 27: 501-542.

Lafferty KD. 1999. The evolution of trophic transmission. Parasitology Today 15: 111-115.

Lafferty KD. 2008. Ecosystem consequences of fish parasites. Journal of Fish Biology 73: 2083-2093.

Lafferty KD, RF Hechinger, JC Shaw, KL Whitney \& AM Kuris. 2006. Food webs and parasites in a salt marsh ecosystem. In: Colllinge S \& C Ray (eds). Disease ecology: community structure and pathogen dynamics, pp. 119-134. Oxford University Press, Oxford.

Love M \& M Moser. 1983. A checklist of parasites of California, Oregon, and Washington marine and estuarine fishes. NOAA Technical Report, NMFS SSRF-777: 1-576.

Mendelssohn R \& FB Schwing. 2002. Common and uncommon trends in SST and wind stress in the California and Peru-Chile current systems. Progress in Oceanography 53: $141-162$.

Moraga P \& G Muñoz. 2010. Prevalencia, abundancia y caracterización de morfoespecies de sanguijuelas (Annelida: Hirudinea) en peces intermareales de Chile central. Archivos de Medicina Veterinaria 42: 71-78.
Morand S, TH Cribb, M Kulbicki, MC Rigby, C Chauvet, V Dufour, E Faliex, R Galzin, CM Lo, A Lo-Yat \& S Pichelin. 2000. Endoparasite species richness of New Caledonian butterfly fishes: host density and diet matter. Parasitology 121: 65-73.

Moring JR. 1986. Seasonal presence of tidepool fish species in a rocky intertidal zone of northern California, USA. Hydrobiologia 134: 21-27.

Muñoz AA \& FP Ojeda. 1997. Feeding guild structure of a rocky intertidal fish assemblage in central Chile. Environmental Biology of Fishes 49: 471-479.

Muñoz G. 2014. Parasites communities in the clingfish Gobiesox marmoratus from central Chile. Acta Parasitologica 59: 108114.

Muñoz G \& R Castro. 2012. Comunidades de parásitos eumetazoos de peces labrisómidos de Chile central. Revista de Biología Marina y Oceanografía 47: 565-571.

Muñoz G \& Y Cortés. 2009. Parasite communities of a fish assemblage from the intertidal rocky zone of central Chile: similarity and host specificity between temporal and resident fish. Parasitology 136: 1291-1303.

Muñoz G \& N Delorme. 2011. Variaciones temporales de las comunidades de parásitos en peces intermareales de Chile central: hospedadores residentes vs temporales. Revista de Biología Marina y Oceanografía 46: 313-327.

Muñoz G \& M George-Nascimento. 2002. Spiracanthus bovichthys $\mathrm{n}$. gen.n. sp. (Acantocephala: Arhythmacanthidae), a parasite of littoral fishes of the central south coast of Chile. The Journal of Parasitology 88: 141-145.

Muñoz G \& V Olmos. 2007. Revisión bibliográfica de especies ectoparásitas y hospedadoras de sistemas acuáticos de Chile. Revista de Biología Marina y Oceanografía 42: 89-148.

Muñoz G \& V Olmos. 2008. Revisión bibliográfica de especies endoparásitas y hospedadoras de sistemas acuáticos de Chile. Revista de Biología Marina y Oceanografía 43: 173-245.

Muñoz G \& HS Randhawa. 2011. Monthly variation in the parasite communities of the intertidal fish Scartichthys viridis (Blenniidae) from central Chile: are there seasonal patterns? Parasitology Research 109: 53-62.

Muñoz G \& L Zamora. 2011. Ontogenetic variation in parasite infracommunities of the clingfish Sicyases sanguineus (Pisces: Gobiesocidae). The Journal of Parasitology 97: 14-19.

Muñoz, G, V Valdebenito \& M George-Nascimento. 2002. La dieta y la fauna de parásitos metazoos del torito Bovichthys chilensis Regan 1914 (Pisces: Bovichthydae) en la costa de Chile centro-sur: variaciones geográficas y ontogenéticas. Revista Chilena de Historia Natural 75: 661671.

Muñoz G, M George-Nascimento \& R Bray. 2017. Two new species of digeneans (Lecithasteridae and Haploporidae) of the intertidal blenny Scartichthys viridis (Valenciennes) from the central coast of Chile. Acta Parasitologica 62(1): $50-62$. 
Muñoz G, I Valdivia \& Z López. 2014. The life cycle of Prosorhynchoides carvajali (Trematoda: Bucephalidae) involving species of bivalve and fish hosts in the intertidal zone of central Chile. Journal of Helminthology 89: 584-592.

Oliva ME \& MT González. 2005. The decay of similarity over geographical distance in parasite communities of marine fishes. Journal of Biogeography 32: 1327-1332.

Pardo-Gandarillas MC, F Garcías \& M GeorgeNascimento. 2004. La dieta y fauna de endoparásitos del pejesapo Gobiesox marmoratus Jenyns, 1842 (Pisces: Gobiesocidae) en el litoral central de Chile están conectadas pero no correlacionadas. Revista Chilena de Historia Natural 77: 627-637.

Poulin R. 2003. The decay of similarity with geographical distance in parasite communities of vertebrate hosts. Journal of Biogeography 30: 1609-1615.

Poulin R \& S Morand. 2000. The diversity of parasites. The Quarterly Review of Biology 75(3): 277-293.

Rebolledo M, MF Landaeta \& G Muñoz. 2014. Efecto del endoparásito Prosorhynchoides sp. (Trematoda: Bucephalidae) en la capacidad de nado sostenido del baunco Girella laevifrons (Osteichthyes: Kyphosidae). Revista de Biología Marina y Oceanografía 49: 625-630.

Rohde K. 1984. Ecology of marine parasites. Helgoländer Meeresuntersuchungen 37: 5-33.
Russell ES. 1916. Form and function: a contribution to the history of animal morphology, 383 pp. John Murray, London.

Shaw JC, RF Hechinger, KD Lafferty \& AM Kuris. 2010. Ecology of the brain trematode Euhaplorchis californiensis and its host, the California killifish (Fundulus parvipinnis). The Journal of Parasitology 96: 482-490.

Thieltges DW, BL Fredensborg \& R Poulin. 2009. Geographical variation in metacercarial infection levels in marine invertebrate hosts: parasite species character versus local factors. Marine Biology 156: 983-990.

Williams HH, K MacKenzie \& AM McCarthy. 1992. Parasites as biological indicators of the population biology, migrations, diet, and phylogenetics of fish. Reviews in Fish Biology and Fisheries 2: 144-176.

Yoshiyama RM. 1981. Distribution and abundance patterns of rocky intertidal fishes in central California. Environmental Biology of Fishes 6: 315-332.

Yoshiyama RM, C Sassaman \& RN Lea. 1986. Rocky intertidal fish communities of California: temporal and spatial variation. Environmental Biology of Fishes 17: 23-40.

Ziêtara MS, DY Lebedeva, G Munoz \& J Lumme. 2012. A monogenean fish parasite, Gyrodactylus chileani n. sp., belonging to a novel marine species lineage found in the South-Eastern Pacific and the Mediterranean and North Seas. Systematic Parasitology 83: 159-167. 
Appendix 1 List of intertidal fish species fromcentral Chile and central Califomia with their parasite speciesand the literature sourcesfromwhere this information was gathered are indicated. *New record from fishes sampled between 2013-2015 during Project FONDECrT1130304 in several localities of central Chile (32-37\%) / Lista de las especies de peces intermareales de Chile central y California central con sus especies de parásitos y la fuentes literarias de donde se obtuvo la información indicada. *Nuevos registros de peces muestreados entre 2013 y 2015 durante el Proyecto FONDECYT 1130304 en varias localidades de Chile central $\left(32-37^{\circ} \mathrm{S}\right)$

\begin{tabular}{|c|c|c|c|c|}
\hline Family / Host species & Group of parasite & Family of parasite & Parasite species & Source \\
\hline \multicolumn{5}{|l|}{ Bovichthydae } \\
\hline \multirow[t]{15}{*}{ Bovichtus chilensis Regan, 1913} & Acanthocephala & Polymorphidae & Corynosoma sp. & Muñoz \& Olmos 2008 \\
\hline & Acanthocephala & Arhythmacanthidae & Hypoechinorhynchus magellanicus (Szidat, 1950) & Muñoz \& Olmos 2008 \\
\hline & Acanthocephala & Arhythmacanthidae & Spiracanthus bovichthys Muñoz \& George-Nascimento, 2002 & Muñoz \& George-Nascimento 2002 \\
\hline & Annelida & Piscicolidae & Piscicolidae gen. sp. & Moraga \& Muñoz 2010 \\
\hline & Copepoda & Caligidae & Caligus sp. & Muñoz \& Olmos 2007 \\
\hline & Copepoda & Caligidae & Lepeophtheirus zbigniewi Castro-Romero \& Baeza-Kuroki, 1981 & * New record \\
\hline & Copepoda & Pennellidae & Trifur tortuosus Wilson, 1917 & Muñoz \& Olmos 2007 \\
\hline & Copepoda & Bomolochidae & Holobomolochus chilensis Cressey \& Cressey, 1985 & Muñoz \& Olmos 2007 \\
\hline & Digenea & Derogenidae & Hemipera cribbi Díaz, Muñoz \& George-Nascimento, 2016 & Díaz, Muñoz \& George-Nascimento 2016 \\
\hline & Digenea & Lecithasteridae & Lecithaster cf. macrocotyle Szidat \& Graefe, 1967 & * New record \\
\hline & Monogenea & Microcotylidae & Microcotyle sp. & * New record \\
\hline & Nematoda & Philometridae & Philometra sp. & Muñoz \& Olmos 2008 \\
\hline & Nematoda & Cystidicolidae & Similascarophis chilensis Muñoz, Gonzalez \& George-Nascimento, 2004 & * New record \\
\hline & Nematoda & Cystidicolidae & Similascarophis maulensis Muñoz, González \& George-Nascimento, 2004 & Muñoz \& Olmos 2008 \\
\hline & Nematoda & Spiruridae & Spiruridae gen. sp. & Muñoz \& Olmos 2008 \\
\hline \multicolumn{5}{|l|}{ Clinidae } \\
\hline \multirow[t]{4}{*}{ Gibbonsia metzi Hubbs, 1952} & Digenea & Opecoelidae & Genitocotyle acirrus Park, 1937 & Love \& Moser 1983 \\
\hline & Digenea & Opecoelidae & Helicometrina elongata Noble \& Park, 1937 & Love \& Moser 1983 \\
\hline & Digenea & Gorgoderidae & Phyllodistomum borisbychowski Caballero \& Caballero, 1969 & Love \& Moser 1983 \\
\hline & Digenea & Opecoelidae & Pseudopecoelus gibbonsiae Manter \& Van Cleave, 1951 & Love \& Moser 1983 \\
\hline \multirow[t]{4}{*}{ Gibbonsia montereyensis Hubbs, 1927} & Digenea & Hemiuridae & Genolinea laticauda Manter, 1925 & Love \& Moser 1983 \\
\hline & Digenea & Opecoelidae & Helicometrina elongata Noble \& Park, 1937 & Love \& Moser 1983 \\
\hline & Digenea & Opecoelidae & Podocotyle sp. & Love \& Moser 1983 \\
\hline & Digenea & Hemiuridae & Lecithochirium exodicum (Mc Farlane, 1936) & Love \& Moser 1983 \\
\hline \multicolumn{5}{|c|}{ (2) } \\
\hline \multirow[t]{6}{*}{ Artedius harringtoni (Starks, 1896) } & Cestoda & Bothriocephalidae & Bothriocephalus scorpii Müller, 1776 & Love \& Moser 1983 \\
\hline & Copepoda & Lernaeopodidae & Clavella parva Wilson, 1912 & Love \& Moser 1983 \\
\hline & Copepoda & Chondracanthidae & Haemobaphes intermedius Kabata, 1967 & Love \& Moser 1983 \\
\hline & Digenea & Acanthocolpidae & Stephanostomum californicum Manter \& Van Cleave, 1951 & Love \& Moser 1983 \\
\hline & Nematoda & Cystidicolidae & Ascarophis sebastodis Olsen, 1952 & Love \& Moser 1983 \\
\hline & Nematoda & Anisakidae & Contracaecum sp. & Love \& Moser 1983 \\
\hline \multirow[t]{5}{*}{ Clinocottus analis (Girard, 1858) } & Annelida & Piscicolidae & Heptacyclus buthi (Burreson \& Kalman, 2006) & Burreson \& Kalman 2006 \\
\hline & Digenea & Hemiuridae & Genolinea laticauda Manter, 1925 & Love \& Moser 1983 \\
\hline & Digenea & Hemiuridae & Genolinea montereyensis Annereaux, 1947 & Love \& Moser 1983 \\
\hline & Digenea & Opecoelidae & Helicometrina elongata Noble \& Park, 1937 & Love \& Moser 1983 \\
\hline & Digenea & Opecoelidae & Helicometrina nimia Linton, 1910 & Love \& Moser 1983 \\
\hline
\end{tabular}


Appendix 1 Continued / Continuación

\begin{tabular}{|c|c|c|c|c|}
\hline Family / Host species & Group of parasite & Family of parasite & Parasite species & Source \\
\hline & Digenea & Opecoelidae & Opecoelus adsphaericus Manter \& Van Cleave, 1951 & Love \& Moser 1983 \\
\hline & Digenea & Opecoelidae & Opecoelus cameroni (Caballero \& Caballero, 1969) & Love \& Moser 1983 \\
\hline & Digenea & Opecoelidae & Podocotyle californica Park, 1937 & Love \& Moser 1983 \\
\hline \multirow[t]{10}{*}{ Myxodes viridis Valenciennes, 1836} & Acanthocephala & Polymorphidae & Corynosoma sp. & * New record \\
\hline & Acanthocephala & Arhythmacanthidae & Hypoechinorhynchus spp. & * New record \\
\hline & Acanthocephala & Rhadinorhynchidae & Rhadinorhynchus sp. & * New record \\
\hline & Annelida & Piscicolidae & Piscicolidae gen. sp. & * New record \\
\hline & Copepoda & Chondracanthidae & Acanthochondria ophiidi (Kroyer, 1863) & * New record \\
\hline & Copepoda & Caligidae & Lepeophtheirus zbigniewi Castro-Romero \& Baeza-Kuroki, 1981 & * New record \\
\hline & Copepoda & Pennellidae & Trifur sp. & * New record \\
\hline & Digenea & Opecoelidae & Helicometrina cf. nimia Linton, 1910 & * New record \\
\hline & Digenea & Derogenidae & Hemipera cribbi Díaz, Muñoz \& George-Nascimento, 2016 & Díaz et al. 2016 \\
\hline & Digenea & Lecithasteridae & Lecithaster cf. macrocotyle Szidat \& Graefe, 1967 & * New record \\
\hline \multirow{11}{*}{ Oligocottus maculosus Girard, 1856} & Annelida & Piscicolidae & Heptacyclus buthi (Burreson \& Kalman, 2006) & Burreson \& Kalman 2006 \\
\hline & Copepoda & Chondracanthidae & Haemobaphes intermedius Kabata, 1967 & Love \& Moser 1983 \\
\hline & Copepoda & Bomolochidae & Hamaticolax spinulus (Cressey, 1969) & Love \& Moser 1983 \\
\hline & Digenea & Hemiuridae & Genolinea laticauda Manter, 1925 & Love \& Moser 1983 \\
\hline & Digenea & Lecithasteridae & Lecithaster gibbosus Rudolphi, 1802 & Love \& Moser 1983 \\
\hline & Digenea & Opecoelidae & Podocotyle califórnica Park, 1937 & Love \& Moser 1983 \\
\hline & Digenea & Hemiuridae & Tubulovesicula lindbergi (Layman, 1930) & Love \& Moser 1983 \\
\hline & Monogenea & Gyrodactylidae & Gyrodactylus maculosi Cone \& Rotn, 1993 & Cone \& Roth 1993 \\
\hline & Nematoda & Anisakidae & Anisakis sp. & Love \& Moser 1983 \\
\hline & Nematoda & Anisakidae & Contracaecum sp. & Love \& Moser 1983 \\
\hline & Nematoda & Guyanemidae & Pseudodelphis oligocotti Adamson \& Roth, 1990 & Bennett 1999 \\
\hline \multirow[t]{4}{*}{ Oligocottus snyderi Greeley, 1898} & Annelida & Piscicolidae & Heptacyclus buthi (Burreson \& Kalman, 2006) & Burreson \& Kalman 2006 \\
\hline & Digenea & Lecithasteridae & Lecithaster gibbosus Rudolphi, 1802 & Love \& Moser 1983 \\
\hline & Digenea & Opecoelidae & Podocotyle californica Park, 1937 & Love \& Moser 1983 \\
\hline & Digenea & Zoogonidae & Zoogonoides viviparous (Olsson, 1868) & Love \& Moser 1983 \\
\hline \multirow[t]{8}{*}{ Scorpaenichthys marmoratus (Ayres, 1854) } & Annelida & Piscicolidae & Malmiana diminuta (Burrenson, 1977) & Love \& Moser 1983 \\
\hline & Copepoda & Chondracanthidae & Chondracanthus gracilis Fraser, 1920 & Love \& Moser 1983 \\
\hline & Copepoda & Chondracanthidae & Chondracanthus pinguis Wilson, 1912 & Love \& Moser 1983 \\
\hline & Copepoda & Bomolochidae & Acantholochus venustus (Kabata, 1971) & Love \& Moser 1983 \\
\hline & Copepoda & Caligidae & Lepeophtheirus parviventris Wilson, 1905 & Love \& Moser 1983 \\
\hline & Digenea & Opecoelidae & Genitocotyle acirrus Park, 1937 & Love \& Moser 1983 \\
\hline & Digenea & Hemiuridae & Genolinea laticauda Manter, 1925 & Love \& Moser 1983 \\
\hline & Digenea & Opecoelidae & Podocotyle californica Park, 1937 & Love \& Moser 1983 \\
\hline
\end{tabular}


Appendix 1 Continued / Continuación

\begin{tabular}{|c|c|c|c|c|}
\hline Family / Host species & Group of parasite & Family of parasite & Parasite species & Source \\
\hline & Digenea & Opecoelidae & Podocotyle enophrysi Park, 1937 & Love \& Moser 1983 \\
\hline & Digenea & Opecoelidae & Podocotyle sp. & Love \& Moser 1983 \\
\hline & Digenea & Bucephalidae & Prosorhynchus scapellus McFarlane, 1936 & Love \& Moser 1983 \\
\hline & Digenea & Piscicolidae & Trachelobdella oregonensis (Burrenson, 1976) & Love \& Moser 1983 \\
\hline & Digenea & Hemiuridae & Tubulovesicula lindbergi (Layman, 1930) & Love \& Moser 1983 \\
\hline & Nematoda & Cystidicolidae & Caballeronema wardlei (Smedley, 1934) & Love \& Moser 1983 \\
\hline \multicolumn{5}{|l|}{ Embiotocidae } \\
\hline \multirow[t]{5}{*}{ Micrometrus minimus (Gibbons, 1854) } & Copepoda & Philichthyidae & Colobomatus embiotocae Noble, Collard \& Wilkes, 1969 & Love \& Moser 1983 \\
\hline & Digenea & Opecoelidae & Genitocotyle acirrus Park, 1937 & Love \& Moser 1983 \\
\hline & Digenea & Zoogonidae & Neozoogonus californicus Arai, 1954 & Love \& Moser 1983 \\
\hline & Digenea & Monorchiidae & Postmonorchis donacis Young, 1953 & Love \& Moser 1983 \\
\hline & Digenea & Haplosplanchnidae & Schikhobalotrema girellae (Manter \& Van Cleave, 1951) & Love \& Moser 1983 \\
\hline \multirow[t]{5}{*}{ Gobiesox maeandricus (Girard, 1858) } & Digenea & Opecoelidae & Helicometrina elongata Noble \& Park, 1937 & Love \& Moser 1983 \\
\hline & Digenea & Opecoelidae & Podocotyle gibbonsia Johnson, 1949 & Love \& Moser 1983 \\
\hline & Digenea & Hemiuridae & Lecithochirium exodicum (Mc Farlane, 1936) & Love \& Moser 1983 \\
\hline & Nematoda & Philometridae & Clavinema mariae (Layman, 1930) & Love \& Moser 1983 \\
\hline & Nematoda & Guyanemidae & Pseudodelphis oligocotti Adamson \& Roth, 1990 & Bennett 1999 \\
\hline \multirow[t]{20}{*}{ Gobiesox marmoratus Jenyns, 1842} & Acanthocephala & Polymorphidae & Corynosoma sp. & Pardo-Gandarillas et al. 2004 \\
\hline & Acanthocephala & Arhythmacanthidae & Hypoechinorhynchus sp. & * New record \\
\hline & Acanthocephala & Rhadinorhynchidae & Rhadinorhynchus sp. & * New record \\
\hline & Acanthocephala & Arhythmacanthidae & Spiracanthus bovichthys Muñoz \& George-Nascimento, 2002 & Muñoz \& George-Nascimento 2002 \\
\hline & Annelida & Piscicolidae & Piscicolidae gen. sp. & Pardo-Gandarillas et al. 2004 \\
\hline & Cestoda & - & Pseudophyllidea (larva) & Muñoz 2014 \\
\hline & Cestoda & - & Tetraphyllidea (larva) & Muñoz 2014 \\
\hline & Copepoda & Caligidae & Caligus sp. & * New record \\
\hline & Copepoda & Bomolochidae & Holobomolochus chilensis Cressey \& Cressey, 1985 & Muñoz 2014 \\
\hline & Copepoda & Caligidae & Lepeophtheirus zbigniewi Castro-Romero \& Baeza-Kuroki, 1981 & Muñoz 2014 \\
\hline & Copepoda & Pennellidae & Trifur cf. tortuosus Wilson, 1917 & Muñoz 2014 \\
\hline & Digenea & Aporocotylidae & Aporocotyle sp. & Muñoz \& Olmos 2008 \\
\hline & Digenea & Opecoelidae & Helicometrina cf nimia Linton, 1910 & Muñoz 2014 \\
\hline & Digenea & Derogenidae & Hemipera cribbi Díaz, Muñoz \& George-Nascimento, 2016 & Díaz et al. 2016 \\
\hline & Digenea & Lecithasteridae & Lecithaster cf. macrocotyle Szidat \& Graefe, 1967 & * New record \\
\hline & Digenea & Fellodistomidae & Proctoeces lintoni Siddiqi \& Cable, 1960 & Muñoz 2014 \\
\hline & Monogenea & Microcotylidae & Microcotyle sp. & * New record \\
\hline & Monogenea & Capsalidae & Neobenedenia melleni (MacCallum, 1927) & * New record \\
\hline & Nematoda & Guyanemidae & Pseudodelphis chilensis Muñoz, 2010 & Muñoz 2014 \\
\hline & Nematoda & Cystidicolidae & Similascarophis chilensis Muñoz, Gonzalez \& George-Nascimento, 2004 & * New record \\
\hline
\end{tabular}


Appendix 1 Continued / Continuación

\begin{tabular}{|c|c|c|c|c|}
\hline Family / Host species & Group of parasite & Family of parasite & Parasite species & Source \\
\hline \multirow[t]{12}{*}{ Sicyases sanguineus Müller \& Troschel, 1843} & Annelida & Piscicolidae & Piscicolidae gen. sp. & Muñoz \& Delorme 2011 \\
\hline & Cestoda & & Pseudophyllidea gen. sp. & Muñoz \& Zamora 2011 \\
\hline & Copepoda & Chondracanthidae & Acanthochondria sicyases (Kroyer, 1863) & Muñoz \& Delorme 2011 \\
\hline & Copepoda & Caligidae & Caligus sp. & * New record \\
\hline & Copepoda & Caligidae & Lepeophtheirus sp. & Muñoz \& Zamora 2011 \\
\hline & Copepoda & Pennellidae & Trifur sp. & * New record \\
\hline & Digenea & Opecoelidae & Helicometrina nimia Linton, 1910 & Muñoz \& Delorme 2011 \\
\hline & Digenea & Lecithasteridae & Lecithaster cf. macrocotyle Szidat \& Graefe, 1967 & $*$ New record \\
\hline & Digenea & Fellodistomidae & Proctoeces lintoni Siddiqi \& Cable, 1960 & Muñoz \& Zamora 2011 \\
\hline & Digenea & Fellodistomidae & Proctoeces sp. & Muñoz \& Delorme 2011 \\
\hline & Digenea & Bucephalidae & Prosorhynchoides carvajali Muñoz \& Bott, 2011 & Muñoz et al. 2014 \\
\hline & Monogenea & Gyrodactylidae & Gyrodactylus sp. & Muñoz \& Zamora 2011 \\
\hline \multicolumn{5}{|r|}{ 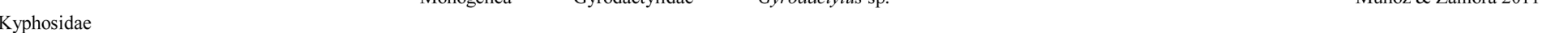 } \\
\hline \multirow[t]{9}{*}{ Girella laevifrons (Tschudi, 1846) } & Acanthocephala & Rhadinorhynchidae & Rhadinorhynchus sp. & * New record \\
\hline & Copepoda & Lernaeopodidae & Clavellotis dilatata (Kroyer, 1863) & Muñoz \& Delorme 2011 \\
\hline & Copepoda & Caligidae & Lepeophtheirus chilensis Wilson, 1905 & Muñoz \& Olmos 2007 \\
\hline & Copepoda & Caligidae & Lepeophtheirus frecuens Castro-Romero \& Baeza, 1984 & Muñoz \& Olmos 2007 \\
\hline & Digenea & Bucephalidae & Prosorhynchoides sp. & Rebolledo et al. 2014 \\
\hline & Monogenea & Capsalidae & Neobenedenia melleni (MacCallum, 1927) & * New record \\
\hline & Nematoda & Anisakidae & Anisakis sp. & * New record \\
\hline & Nematoda & Cystidicolidae & Similascarophis chilensis Muñoz, Gonzalez \& George-Nascimento, 2004 & Muñoz \& Delorme 2011 \\
\hline & Nematoda & Cystidicolidae & Similascarophis maulensis Muñoz, González \& George-Nascimento, 2004 & * New record \\
\hline \multirow[t]{7}{*}{ Graus nigra Philippi, 1887} & Acanthocephala & Polymorphidae & Corynosoma sp. & * New record \\
\hline & Annelida & Piscicolidae & Piscicolidae gen. sp. & Moraga \& Muñoz 2010 \\
\hline & Cestoda & - & Pseudophyllidea gen. sp. (larva) & * New record \\
\hline & Copepoda & Caligidae & Lepeophtheirus chilensis Wilson, 1905 & Muñoz \& Olmos 2007 \\
\hline & Digenea & Lecithasteridae & Lecithaster cf. macrocotyle Szidat \& Graefe, 1967 & * New record \\
\hline & Nematoda & Cystidicolidae & Similascarophis chilensis Muñoz, Gonzalez \& George-Nascimento, 2004 & Muñoz \& Olmos 2008 \\
\hline & Nematoda & Cystidicolidae & Similascarophis maulensis Muñoz, González \& George-Nascimento, 2004 & * New record \\
\hline \multicolumn{5}{|l|}{ Labrisomidae } \\
\hline \multirow[t]{7}{*}{ Auchenionchus microcirrhis (Valenciennes, 1836) } & Acanthocephala & Polymorphidae & Corynosoma sp. & Muñoz \& Castro 2012 \\
\hline & Acanthocephala & Arhythmacanthidae & Hypoechinorhynchus sp. & * New record \\
\hline & Annelida & Piscicolidae & Piscicolidae gen. sp. & Moraga \& Muñoz 2010 \\
\hline & Cestoda & Tentaculariidae & Nybelinia sp. & Muñoz \& Castro 2012 \\
\hline & Cestoda & - & Pseudophyllidea gen. sp. & Muñoz \& Castro 2012 \\
\hline & Cestoda & - & Tetraphyllidea gen. sp. & Muñoz \& Castro 2012 \\
\hline & Copepoda & Chondracanthidae & Acanthochondria ophiidi (Kroyer, 1863) & Muñoz \& Castro 2012 \\
\hline
\end{tabular}


Appendix 1 Continued / Continuación

\begin{tabular}{|c|c|c|c|c|}
\hline Family / Host species & Group of parasite & Family of parasite & Parasite species & Source \\
\hline & Copepoda & Philichthyidae & Colobomatus tenuis Castro Romero \& Muñoz, 2011 & Muñoz \& Castro 2012 \\
\hline & Copepoda & Bomolochidae & Holobomolochus chilensis Cressey \& Cressey, 1985 & Muñoz \& Castro 2012 \\
\hline & Copepoda & Caligidae & Lepeophtheirus zbigniewi Castro-Romero \& Baeza-Kuroki, 1981 & Muñoz \& Olmos 2007 \\
\hline & Copepoda & Pennellidae & Trifur cf. tortuosus Wilson, 1917 & Muñoz \& Castro 2012 \\
\hline & Digenea & Opecoelidae & Helicometrina cf. nimia Linton, 1910 & Muñoz \& Castro 2012 \\
\hline & Digenea & Derogenidae & Hemipera sp. & Muñoz \& Castro 2012 \\
\hline & Digenea & Lecithasteridae & Lecithaster cf. macrocotyle Szidat \& Graefe, 1967 & * New record \\
\hline & Digenea & Bucephalidae & Prosorhynchoides carvajali Muñoz \& Bott, 2011 & Muñoz \& Castro 2012 \\
\hline & Monogenea & Microcotylidae & Microcotyle sp. & * New record \\
\hline & Monogenea & Capsalidae & Neobenedenia melleni (MacCallum, 1927) & Muñoz \& Castro 2012 \\
\hline & Nematoda & Anisakidae & Anisakis sp. & Muñoz \& Castro 2012 \\
\hline & Nematoda & Cystidicolidae & Similascarophis chilensis Muñoz, Gonzalez \& George-Nascimento, 2004 & Muñoz \& Castro 2012 \\
\hline & Nematoda & - & Spirurida gen. sp. & Muñoz \& Castro 2012 \\
\hline \multirow[t]{17}{*}{ Auchenionchus variolosus (Valenciennes, 1836) } & Acanthocephala & Polymorphidae & Corynosoma sp. & Muñoz \& Castro 2012 \\
\hline & Acanthocephala & Arhythmacanthidae & Hypoechinorhynchus spp. & * New record \\
\hline & Acanthocephala & Arhythmacanthidae & Spiracanthus bovichthys Muñoz \& George-Nascimento, 2002 & Muñoz \& George-Nascimento 2002 \\
\hline & Annelida & Piscicolidae & Piscicolidae gen. sp. & Moraga \& Muñoz 2010 \\
\hline & Cestoda & - & Tetraphyllidea gen. sp. & Muñoz \& Castro 2012 \\
\hline & Copepoda & Chondracanthidae & Acanthochondria ophiidi (Kroyer, 1863) & Muñoz \& Castro 2012 \\
\hline & Copepoda & Bomolochidae & Holobomolochus chilensis Cressey \& Cressey, 1985 & Muñoz \& Castro 2012 \\
\hline & Copepoda & Caligidae & Lepeophtheirus zbigniewi Castro-Romero \& Baeza-Kuroki, 1981 & Muñoz \& Castro 2012 \\
\hline & Copepoda & Pennellidae & Trifur cf. tortuosus Wilson, 1917 & Muñoz \& Castro 2012 \\
\hline & Digenea & Opecoelidae & Helicometrina cf. nimia Linton, 1910 & Muñoz \& Castro 2012 \\
\hline & Digenea & Hemiuridae & Hemiuridae gen. sp. & Muñoz \& Castro 2012 \\
\hline & Digenea & Lecithasteridae & Lecithaster sp. & Muñoz \& Castro 2012 \\
\hline & Digenea & Haploporidae & Megasolena sp. & * New record \\
\hline & Digenea & Bucephalidae & Prosorhynchoides carvajali Muñoz \& Bott, 2011 & Muñoz \& Castro 2012 \\
\hline & Monogenea & Microcotylidae & Microcotyle sp. & Muñoz \& Castro 2012 \\
\hline & Monogenea & Capsalidae & Neobenedenia melleni (MacCallum, 1927) & * New record \\
\hline & Nematoda & - & Spirurida gen. sp. & Muñoz \& Castro 2012 \\
\hline \multirow[t]{7}{*}{ Calliclinus geniguttatus (Valenciennes, 1836) } & Acanthocephala & Polymorphidae & Corynosoma sp. & * New record \\
\hline & Acanthocephala & Arhythmacanthidae & Hypoechinorhynchus sp. & * New record \\
\hline & Acanthocephala & Arhythmacanthidae & Spiracanthus bovichthys Muñoz \& George-Nascimento, 2002 & Muñoz \& George-Nascimento 2002 \\
\hline & Annelida & Piscicolidae & Piscicolidae gen. sp. & * New record \\
\hline & Cestoda & - & Pseudophyllidea gen. sp. (larva) & * New record \\
\hline & Cestoda & - & Tetraphyllidea gen. sp. (larva) & * New record \\
\hline & Copepoda & Philichthyidae & Colobomatus temuis Castro Romero \& Munoz, 2011 & * New record \\
\hline
\end{tabular}


Appendix 1 Continued / Continuación

\begin{tabular}{|c|c|c|c|c|}
\hline Family / Host species & Group of parasite & Family of parasite & Parasite species & Source \\
\hline & Copepoda & Bomolochidae & Holobomolochus chilensis Cressey \& Cressey, 1985 & Muñoz \& Castro 2012 \\
\hline & Copepoda & Caligidae & Lepeophtheirus zbigniewi Castro-Romero \& Baeza-Kuroki, 1981 & Muñoz \& Castro 2012 \\
\hline & Copepoda & Pennellidae & Trifur sp. & * New record \\
\hline & Digenea & Opecoelidae & Helicometrina ef. nimia Linton, 1910 & Muñoz \& Castro 2012 \\
\hline & Digenea & Bucephalidae & Prosorhynchoides carvajali Muñoz \& Bott, 2011 & * New record \\
\hline & Monogenea & Microcotylidae & Microcotyle sp. & * New record \\
\hline & Monogenea & Capsalidae & Neobenedenia melleni (MacCallum, 1927) & * New record \\
\hline \multicolumn{5}{|c|}{$x^{2}$} \\
\hline \multirow[t]{4}{*}{ Apodichthys flavidus Girard, 1854} & Cestoda & Bothriocephalidae & Bothriocephalus scorpii (Müller, 1776) & Love \& Moser 1983 \\
\hline & Copepoda & Chondracanthidae & Chondracanthus pusillus Kabata, 1968 & Love \& Moser 1983 \\
\hline & Digenea & Opecoelidae & Podocotyle apodichthysi Park, 1937 & Love \& Moser 1983 \\
\hline & Nematoda & Anisakidae & Anisakis sp. & Love \& Moser 1983 \\
\hline \multicolumn{5}{|l|}{ Stichaeidae } \\
\hline \multirow[t]{6}{*}{ Anoplarchus purpurescens Gill, 1861} & Digenea & Lecithasteridae & Lecithaster gibbosus Rudolphi, 1802 & Love \& Moser 1983 \\
\hline & Digenea & Hemiuridae & Tubulovesicula lindbergi (Layman, 1930) & Love \& Moser 1983 \\
\hline & Nematoda & Anisakidae & Anisakis sp. & Arai 1969 \\
\hline & Nematoda & Cystidicolidae & Ascarophis sebastodis Olsen, 1952 & Arai 1969 \\
\hline & Nematoda & Anisakidae & Contracaecum sp. & Arai 1969 \\
\hline & Nematoda & Toxocaridae & Porrocaecum sp. & Arai 1969 \\
\hline \multirow[t]{6}{*}{ Xiphister atropurpureus (Kittlitz, 1858) } & Copepoda & Chondracanthidae & Chondracanthus pinguis Wilson, 1912 & Love \& Moser 1983 \\
\hline & Copepoda & Caligidae & Lepeophtheirus parviventris Wilson, 1905 & Love \& Moser 1983 \\
\hline & Digenea & Opecoelidae & Podocotyle atomon (Rudolphi, 1802) & Love \& Moser 1983 \\
\hline & Digenea & Opecoelidae & Podocotyle californica Park, 1937 & Love \& Moser 1983 \\
\hline & Digenea & Opecoelidae & Podocotyle reflexa (Creplin, 1825) & Love \& Moser 1983 \\
\hline & Nematoda & Philometridae & Clavinema mariae (Layman, 1930) & Love \& Moser 1983 \\
\hline Xiphister mucosus (Girard, 1858) & Digenea & Opecoelidae & Podocotyle californica Park, 1937 & Love \& Moser 1983 \\
\hline \multicolumn{5}{|l|}{$\begin{array}{l}\text { Tripterygiidae } \\
\text { The }\end{array}$} \\
\hline \multirow[t]{12}{*}{ Helcogrammoides chilensis (Cancino, 1960) } & Acanthocephala & Polymorphidae & Corynosoma sp. & Muñoz \&Delorme 2011 \\
\hline & Annelida & Piscicolidae & Piscicolidae gen. sp. & Muñoz \& Delorme201 1 \\
\hline & Cestoda & & Pseudophyllidea gen. sp. & Muñoz \& Delorme 2011 \\
\hline & Cestoda & - & Tetraphyllidea gen. sp. & Muñoz \& Delorme 2011 \\
\hline & Copepoda & Bomolochidae & Holobomolochus chilensis Cressey \& Cressey, 1985 & Muñoz \& Delorme 2011 \\
\hline & Copepoda & Bomolochidae & Holobomolochus dawsoni Cressey \& Cressey, 1985 & Muñoz \& Olmos 2007 \\
\hline & Copepoda & Caligidae & Lepeophtheirus zbigniewi Castro-Romero \& Baeza-Kuroki, 1981 & * New record \\
\hline & Digenea & Opecoelidae & Helicometrina cf. nimia Linton, 1910 & Muñoz \& Delorme 2011 \\
\hline & Digenea & Derogenidae & Hemipera sp. & * New record \\
\hline & Digenea & Lecithasteridae & Lecithaster sp. & Muñoz \& Delorme 2011 \\
\hline & Digenea & Bucephalidae & Prosorhynchoides carvajali Muñoz \& Bott, 2011 & Muñoz et al. 2014 \\
\hline & Monogenea & Gyrodactylidae & Gyrodactylus chileani Ziętara, Lebedeva, Muñoz \& Lumme, 2012 & Ziętara et al. 2012 \\
\hline \multirow[t]{6}{*}{ Helcogrammoides cunninghami (Smitt, 1898) } & Annelida & Piscicolidae & Piscicolidae gen. sp. & * New record \\
\hline & Cestoda & - & Pseudophyllidea gen. sp. (larva) & * New record \\
\hline & Cestoda & - & Tetraphyllidea gen. sp. (larva) & * New record \\
\hline & Copepoda & Bomolochidae & Holobomolochus chilensis Cressey \& Cressey, 1985 & * New record \\
\hline & Copepoda & Caligidae & Lepeophtheirus zbigniewi Castro-Romero \& Baeza-Kuroki, 1981 & * New record \\
\hline & Digenea & Lecithasteridae & Lecithaster cf. macrocotyle Szidat \& Graefe, 1967 & * New record \\
\hline
\end{tabular}

